\title{
Comparative ultrasonographic characterization of the pelvis in clinically normal horses and donkeys
}

\author{
Ahmed Sharshar ${ }^{1 *}$, Mohamed El-Sunsafty ${ }^{1}$, Tarik Misk ${ }^{1}$, \\ Shaaban Gadallah', and Mustafa Fadel ${ }^{2}$ \\ ${ }^{I}$ Department of Surgery, Anesthesiology and Radiology. Faculty of Veterinary Medicine, University of Sadat \\ City, Sadat City, Menoufia, Egypt \\ ${ }^{2}$ Animal Reproduction and Research Institute, Cairo, Egypt
}

\begin{abstract}
SHARSHAR, A., M. EL-SUNSAFTY, T. MISK, S. GADALLAH, M. FADEL: Comparative ultrasonographic characterization of the pelvis in clinically normal horses and donkeys. Vet. arhiv 88, 607-625, 2018.
\end{abstract}

\section{ABSTRACT}

This study was conducted to provide detailed a comparative ultrasonographic description of the pelvis in clinically normal horses and donkeys. It was carried out on 48 mature animals ( 30 horses and 18 donkeys). Evaluation of the pelvis was performed using transcutaneous and transrectal techniques. The following structures were examined: the tubera sacrales (the shape and distance between them and the distance between each of them and the first sacral spinous process), the ilial wing, the tuber coxae, the ilial body, the hip joint, the tuber ischii, the third trochanter, the appearance and measurements of the dorsal and lateral parts of the dorsal sacroiliac ligament and the thoracolumbar fascia, the ischiatic table, the obturator foramen and its contents, the pubis, the medial aspect of the acetabulum and the ilial body, the sacroiliac joint and the ventral aspect of the sacrum. For each evaluated structure, the results obtained were compared between horses and donkeys. A high correspondence was found between the pelvises of horses and donkeys concerning their ultrasonographic appearance and measurements, except for the cross sectional area of both dorsal parts of the dorsal sacroiliac ligament-thoracolumbar fascia combination, and the sacroiliac joint width, where there were significant differences between them.

Key words: donkey; horse; pelvic ultrasonography; transcutaneous; transrectal

\section{Introduction}

Infections and injuries of the pelvis are common in equine species. They are one of the major causes of hind limb lameness that greatly affects animal performance and may lead to its culling (ALMANZA and WHITCOMB, 2003; PILSWORTH, 2003; BERTONI

\footnotetext{
${ }^{*}$ Corresponding author:

Ahmed Sharshar, Department of Animal Surgery, Anesthesiology and Radiology, Faculty of Veterinary medicine, University of Sadat City, Postal code: 32897, Sadat City, Egypt, Phone: +20 1121037 741; Fax: +20 482612 225; E-mail: ahmed.sharshar@ vet.usc.edu.eg
} 
A. Sharshar et al.: Comparative ultrasonographic characterization of the pelvis in clinically normal horses and donkeys

et al, 2013). The complex anatomic structure of the pelvis, coupled with the animal's body size, makes diagnosis of its injuries a challenge to equine practitioners (HAUSSLER et al, 1999; TOMLINSON et al, 2001; PILSWORTH, 2003; VERHEYEN and WOOD, 2004; ENGELI et al, 2006; WHITCOMB, 2012; HEAD, 2014).

Pelvic evaluation is carried out by various techniques including X-ray, computed tomography $(\mathrm{CT})$, magnetic resonance imaging (MRI) and nuclear scintigraphy. Each one of these has advantages and disadvantages (HOGAN et al, 1995; TOMLINSON et al, 2001; BARRETT et al, 2006; BUTLER et al, 2008; DEWÉ et al, 2008; POWELL, 2011; HEAD, 2014, SHIELDS et al, 2015). X-rays, CT and MRI show excellent details of the pelvic osseous structures. On the other hand, they give little information about the soft tissues. The high cost of the equipment and the danger of fracture displacement involved in positioning the animal for examination limit their wider use in most equine clinics (GEISSBÜHLER et al, 1998; DYSON and MURRAY, 2003; BARRETT et al, 2006; TRUMP et al, 2011 WHITCOMB et al, 2011). Nuclear scintigraphy was used for diagnosis of pelvic infections or injuries related to the sacroiliac region (DYSON et al, 2003a,b), ischial tuberosity and the third trochanter (GEISSBÜHLER et al, 1998; DAVENPORT-GOODALL and ROSS, 2004; SHIELDS et al, 2015). Nuclear scintigraphy is more sensitive than other diagnostic tools. In addition, the animal is examined while maintained in a standing position. so it can be protected from the risk associated with general anesthesia. Nuclear scintigraphy has many disadvantages in that it is a nonspecific diagnostic tool that gives little information about the nature of the pathological process. In addition, the quality of the obtained image is greatly affected by pelvic muscle mass, animal motion and the absorption effect of the urinary bladder. Moreover, the equipment is highly expensive, thus it is not suitable for all veterinary hospitals (ERICHSEN and BERGER, 2001; DAVENPORT-GOODALL, and ROSS, 2004; BUTLER et al, 2008). Ultrasonography has been used recently for pelvic examination (WALKER et al 2012; WHITCOMB, 2012). It can give diagnostic information about the bone surfaces, pelvic joints and soft tissue. It does not require general anesthesia, and the animal is examined while maintained in a standing position, thus eliminating the dangers associated with animal casting (TOMLINSON et al, 2003; DEWÉ et al, 2008; BRENNER and WHITCOMB, 2009; BERTONI et al, 2013; HEAD, 2014; SHIELDS et al, 2015). Moreover, ultrasonography constitutes a rapid, non-invasive and less expensive method for diagnosis of pelvic injury (PILSWORTH, 2011; POWELL, 2011).

Several reports have described the normal and abnormal ultrasonographic appearance of the horse's pelvis (TOMLINSON et al, 2001; KERSTEN and EDINGER, 2004; ENGELI et al, 2006; WALKER et al, 2012; WHITCOMB, 2012). According to our knowledge, there is no available data concerning the normal ultrasonographic characterization of a donkey's pelvis despite their wide distribution all over the world. The purpose of this 
A. Sharshar et al.: Comparative ultrasonographic characterization of the pelvis in clinically normal horses and donkeys

study is to provide a detailed comparative ultrasonographic description of the pelvis in clinically normal horses and donkeys, in order to use the obtained data as a guide for future pelvic examination studies. We assume that there are no major differences between the ultrasonographic images of horses and donkeys.

\section{Materials and methods}

The present study was carried out at the Surgery, Anesthesiology and Radiology Department of the Faculty of Veterinary Medicine, University of Sadat City, Egypt. The study protocol followed the guidelines of the faculty for the use and care of animals. The study was carried out on 48 clinically normal mature male animals of native breed (30 horses and 18 donkeys). The animals had no previous history of hind limb lameness or back pain. The mean age of the horses was 19.5 years (range: 13 to 25 years old) and their mean body weight $420 \mathrm{~kg}$ (range, 350 to $500 \mathrm{~kg}$ ). The mean age of the donkeys was 8 years (range, 7 to 10 years) and mean body weight $197 \mathrm{~kg}$ (range, 150 to $250 \mathrm{~kg}$ ). The animals were owned by the institution. They were used for teaching purposes and scheduled for euthanasia. In all cases, the reason for euthanasia was unrelated to any pathology affecting the pelvis. The pelvises of 6 animals ( 3 horses and 3 donkeys) were dissected to assess the ultrasonographic findings. All animals were inspected from behind while standing squarely on a flat surface in order to assess the symmetry of the pelvis and the hind quarter musculature. The animals were examined while moving on soft and hard ground, followed by a flexion test of the proximal hind limbs. External and rectal palpation of pelvic components was performed for detection of any abnormalities and/ or response to pain. The animals included in the study were free from any detectable lameness when moving handheld on a hard surface, and on both hard and soft surfaces on the lunge. The response to the proximal limb flexion test of the hind limbs was negative. No animals with asymmetry of the sides of the pelvis were included in the study.

Animals were controlled in a stanchion, having been sedated by intravenous administration of Xylazine hydrochloride (Xylaject ${ }^{\circledR}: 2 \%$ sol. ADWIA Co., Egypt) at a dose of $1.1 \mathrm{mg} / \mathrm{kg}$ b.m. i $/ \mathrm{v}$, followed by induction of caudal posterior epidural analgesia using $2 \%$ lidocaine hydrochloride (Debucaine ${ }^{\circledR} \%$ El- Nasr Pharm. Chemicals co. for Al-Debeiky Pharm. Egypt) at a dose of $0.35 \mathrm{mg} / \mathrm{kg}$ b.m. Animal preparation included hair clipping and cleansing the skin overlaying the pelvis using ethyl alcohol, followed by spreading the acoustic gel.

Ultrasonographic examinations were performed using an ultrasound unit (Esaote mylab one-507, Italy) equipped with 6.6 to $18 \mathrm{MHz}$ micro-convex, linear array tendon and rectal linear probes. For complete pelvic evaluation both transcutaneous and transrectal ultrasonographic examinations were carried out on the same basis described by WALKER et al. (2012), HEAD (2014), and WHITCOMB and VAUGHAN (2015). The examined 
A. Sharshar et al.: Comparative ultrasonographic characterization of the pelvis in clinically normal horses and donkeys

structures, probe type, recorded parameters, recommended frequency and depth are listed in Tables 1 and 2. The highest-frequency that penetrated the area of interest was used to achieve the best-quality images.

Table 1. The structures examined during transcutaneous examination, recorded parameters, probe type used, recommended frequency and depth

\begin{tabular}{|c|c|c|c|c|}
\hline $\begin{array}{l}\text { Examined } \\
\text { structure }\end{array}$ & Probe type & $\begin{array}{l}\text { Scanning } \\
\text { frequency } \\
\text { MHz }\end{array}$ & $\begin{array}{l}\text { Scanning } \\
\text { depth } \\
\text { cm }\end{array}$ & Recorded parameters \\
\hline Tubera sacrales & Microconvex & 10 & $5-6$ & $\begin{array}{c}\text { Shape. } \\
\text { Depth from skin surface, distance } \\
\text { between them at the most dorsal point } \\
\text { and the distance between the medial } \\
\text { aspect of each of them and the most } \\
\text { dorsal part of first sacral spinous } \\
\text { process }\end{array}$ \\
\hline Ilial wing & Microconvex & 6.6 & $8-12$ & Shape \\
\hline $\begin{array}{l}\text { Lateral part of the } \\
\text { dorsal sacroiliac } \\
\text { ligament }\end{array}$ & Microconvex & $8-10$ & $4-8$ & $\begin{array}{c}\text { Shape } \\
\text { Thickness } \\
\text { Attachment to the lateral sacral crest }\end{array}$ \\
\hline $\begin{array}{l}\text { Dorsal part of the } \\
\text { dorsal sacroiliac } \\
\text { ligament - } \\
\text { thoracolumbar } \\
\text { fascia combination }\end{array}$ & $\begin{array}{l}\text { Linear array } \\
\text { tendon }\end{array}$ & $8-14$ & $4-6$ & $\begin{array}{l}\text { Echogenicity and linear fiber pattern. } \\
\text { Cross sectional area and thickness }\end{array}$ \\
\hline Tuber coxae & Microconvex & 10 & $5-8$ & $\begin{array}{c}\text { Shape } \\
\text { Ventral muscle attachment }\end{array}$ \\
\hline Ilial body & Microconvex & 6.6 & $8-12$ & Shape \\
\hline Tuber ischii & Microconvex & $6.6-10$ & $5-10$ & Shape. \\
\hline Third trochanter & Microconvex & $6.6-8$ & $8-12$ & $\begin{array}{l}\text { Shape. } \\
\end{array}$ \\
\hline Hip joint & Microconvex & 6.6 & $5-10$ & $\begin{array}{c}\text { Joint space } \\
\text { Femoral head and acetabulum }\end{array}$ \\
\hline Pelvic muscles & Microconvex & $6.6-10$ & $4-12$ & Appearance \\
\hline
\end{tabular}


A. Sharshar et al.: Comparative ultrasonographic characterization of the pelvis in clinically normal horses and donkeys

Table 2. The structures examined during transrectal examination, parameters recorded, probe type used, recommended frequency and depth

\begin{tabular}{|l|c|c|c|c|}
\hline $\begin{array}{l}\text { Examined } \\
\text { structure }\end{array}$ & Probe type & $\begin{array}{c}\text { Scanning frequency } \\
\text { MHz }\end{array}$ & $\begin{array}{c}\text { Scanning depth } \\
\mathrm{cm}\end{array}$ & Recorded parameters \\
\hline $\begin{array}{l}\text { Pelvis } \\
\text { symphysis }\end{array}$ & Microconvex & 10 & $4-7$ & Appearance \\
\hline Ischiatic table & Linear & 10 & $4-7$ & Shape \\
\hline $\begin{array}{l}\text { Medial aspect of } \\
\text { the acetabulum }\end{array}$ & Linear & 10 & $4-7$ & Shape \\
\hline Ilial body & Linear & 10 & $4-7$ & Shape \\
\hline $\begin{array}{l}\text { Ventral aspect } \\
\text { of the sacrum }\end{array}$ & Linear & 10 & $4-7$ & Shape \\
\hline $\begin{array}{l}\text { Obturator } \\
\text { foramen (OF) } \\
\text { and its contents }\end{array}$ & $\begin{array}{c}\text { Microconvex } \\
\text { and linear }\end{array}$ & 10 & $4-7$ & $\begin{array}{c}\text { Shape } \\
\text { Contents (blood } \\
\text { vessels and nerve) }\end{array}$ \\
\hline Sacroiliac joint & linear & 10 & $4-7$ & Shape and width \\
\hline
\end{tabular}

Statistical analyses. For each measured structure, the mean, standard error (SE) and range of values were calculated. The differences in values between the right half of the pelvises of all those examined were analyzed using a nonpaired $t$ test. The same test was repeated to analyze the differences in values between the left half of the pelvis of all the examined animals. The paired $t$ test was used to compare the differences in values between the right and the left sides of each species. For all tests, significance was set at $\mathrm{P}<0.05$.

\section{Results}

The pelvises of both donkeys and horses showed the same ultrasonographic appearance during both transcutaneous and transrectal examinations. During the transcutaneous examination both tubera sacrales were imaged as hyperechoic convex arches with some irregularity on their surface. They were separated from each other by a hypoechoic zone. Each one of them was covered with a thin echogenic layer constituting the dorsal part of the dorsal sacroiliac ligament and the thoracolumbar fascia (Fig. 1A and 1B). The spinous process of the first sacral vertebra was imaged as a small hyperechoic area midway between the tubera sacrales. The shadow artifact created by it masked observation of the sacral vertebral bodies (Fig. 1A). The mean distance between the two tubera sacrales, as well as the distance between them and the most dorsal point of the first sacral spinous process are presented in Table 3.

The dorsal part of the dorsal sacroiliac ligament and the thoracolumbar fascia appeared in the transverse scan as a homogenous S-shaped echogenic structure extending laterally to cover the proximal part of the tuber sacrale, and fused medially with the counterpart opposite side, at the level of the dorsal spinous processes of the sacral vertebrae. In all 
examined donkeys and 20 of the examined horses, the thoracolumbar fascia was fused medially to the dorsal potion of the dorsal sacroiliac ligament (Fig. 1B) and dorsally in the rest (10 horses) of the examined horses (Fig. 1C). On the longitudinal scan, the dorsal portion of the dorsal sacroiliac ligament and the thoracolumbar fascia appeared as two homogenous echogenic layers. At the cranial border of tuber sacrale, they were separated from each other by an anechoic zone and completely fused together at the level of the most dorsal point of the tuber sacrale without a clear separating border (Fig.1D). The mean thickness and cross-sectional area of the dorsal potion of the dorsal sacroiliac ligament- thoracolumbar fascia combination, in both horses and donkeys, is presented in Table 3.
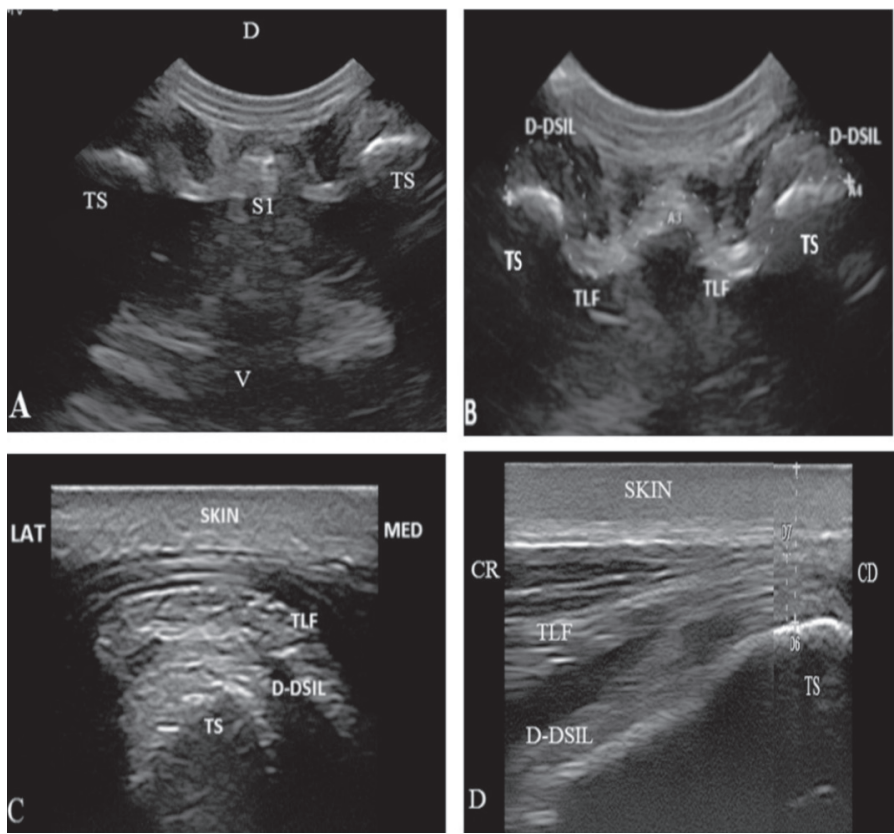

Fig. 1A. Transverse ultrasonographic image of the dorsal sacroiliac region of a 7 year old donkey, showing both tuber sacrale (TS) and the most dorsal point of first sacral spinous process (S1). $\mathrm{D}$, dorsal, V, ventral. Fig. 1B - Transverse ultrasonographic image of the dorsal sacroiliac region of a 10 year old donkey showing both tuber sacrale (TS), the dorsal part of the dorsal sacroiliac ligament (D-DSIL) fused medially with the thoracolumbar fascia (TLF). Fig. 1C - Transverse ultrasonographic image at the level of the most portion point of the tuber sacral (TS) in a 17 year old stallion, showing both the dorsal part of the dorsal sacroiliac ligament (D-DSIL) and the thoracolumbar fascia (TLF) fused dorsally. LAT, lateral. MED, medial. Fig. 1D - Compound longitudinal ultrasonographic image at the level of the tuber sacral (TS) of a 9 year old donkey showing; the dorsal part of the dorsal sacroiliac ligament (D-DSIL) completely fused with the thoracolumbar fascia (TLF) at the most dorsal point of the TS. CR, cranial, CD, caudal. 
A. Sharshar et al.: Comparative ultrasonographic characterization of the pelvis in clinically normal horses and donkeys

The lateral portion of the dorsal sacroiliac ligament appeared as a slightly irregular hyperechoic line extending ventrolaterally at an angle to the vertical axis. At its ventrolateral end, it was attached to a smooth hyperechoic linear structure, which constitutes the lateral sacral crest (Fig. 2A). The mean thickness of the lateral portion of the dorsal sacroiliac ligament in both horses and donkeys is presented in Table 3.
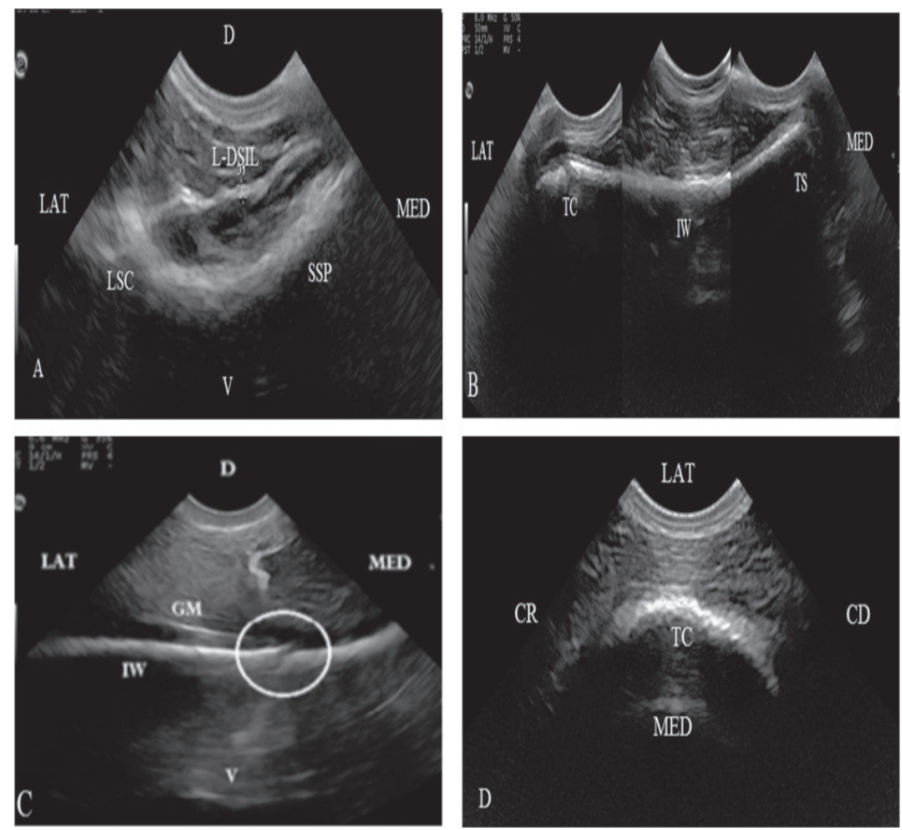

Fig. 2A - Transverse ultrasonographic image of a 10 year old donkey; showing the lateral portion of the dorsal sacroiliac ligament (L-DSIL) attached to the lateral sacral crest (LSC) and the sacral spinous process (SSP). LAT, lateral, MED, medial, D dorsal, V, ventral. Fig. 2B - Compound longitudinal ultrasonographic image of the right ilial wing (IW) in a 7 year old donkey. The ilial wing appeared as a hyperechoic concave arch extending from the tuber sacral (TS) medially to the tuber coxae (TC) laterally and is covered with a homogenous echogenic gluteal muscle mass. LAT, lateral, MED, medial. Fig. 2C - Longitudinal ultrasonographic image of the med-ilial wing (IW) region in a 20 year old stallion showing a gap like fracture artifact (circle) at the level of the gluteal muscle tendon (GM) insertion. LAT, lateral, MED, medial, D dorsal, V, ventral. Fig. 2D Longitudinal ultrasonographic image of the right tuber coxae (TC) of a 9 year old donkey. LAT, lateral, MED, medial, CR, cranial, CD caudal.

The ilial wing was imaged as a continuous smooth concave hyperechoic arch extending laterally from the tuber sacrale to the tuber coxae, covered with a homogenous hypoechoic gluteal muscle mass (Fig. 2B). A gap like fracture was imaged during examination of the medial ilial wing region (Fig. 2C). The tuber coxae appeared as a 
A. Sharshar et al.: Comparative ultrasonographic characterization of the pelvis in clinically normal horses and donkeys

slightly convex hyperechoic arch with a slightly irregular surface (Fig. 2D). The ilial body appeared as a concave hyperechoic line extending caudoventrally from the tuber coxae to the acetabulum (Fig. 3A).
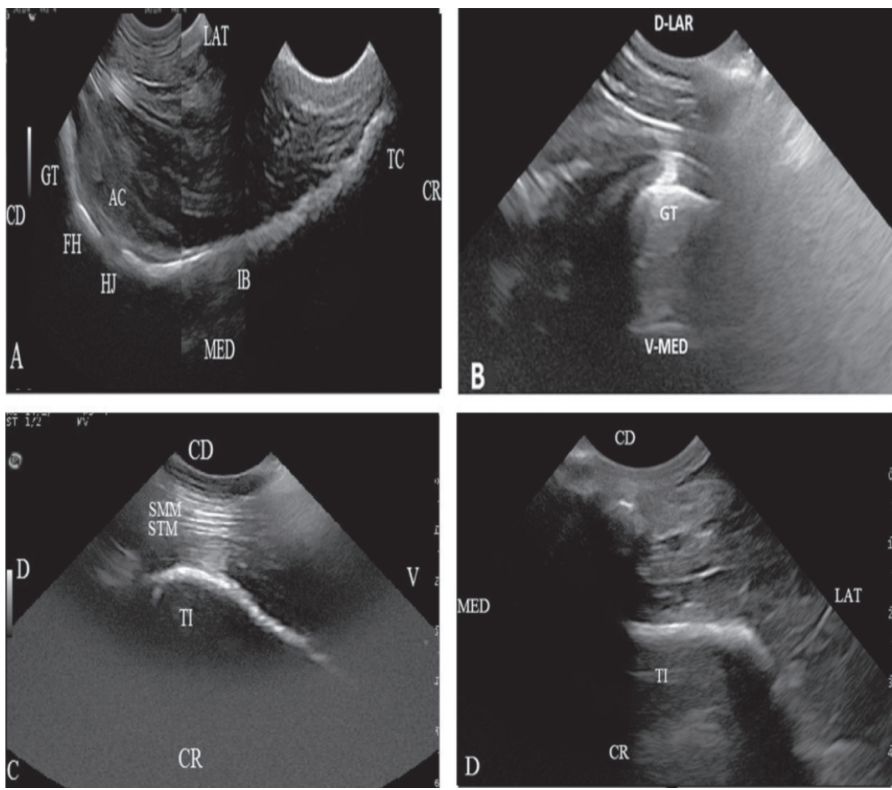

Fig. 3A - Compound longitudinal ultrasonographic image of the right ilial body and hip joint in a 10 year old donkey. TC; tuber coxae, IB; ilial body, HJ, hip joint, FH, femoral head, AC, acetabulum, GT, greater trochanter. LAT, lateral, MED, medial, CR, cranial, CD caudal. Fig. 3B - Transverse ultrasonographic image of the left greater trochanter (GT) of a 10 year old donkey. The probe was positioned in a dorso-lateral (D-LAT) to ventro-medial (V-MED) direction. Fig. 3C. Transverse ultrasonographic image of the left tuber ischii (TI) of an 8 year old donkey. The probe was located caudo-ventral to the TI and directed slightly craniodorsally. The tuber ischii

(TI) are covered with two echogenic muscle layers constituting semimembranosus (SMM) and semitendinosus (STM) muscles. CD, caudal, CR cranial, D dorsal, V, ventral. Fig. 3D.

Longitudinal ultrasonographic image of tuber ischii (TI) of the same animal in Fig. 3C. MED, medial, LAT, lateral, CR, cranial, CD, caudal.

The hip joint was located at the caudal end of the ilial body, where its surface changed from concave to convex. The cranial part of the hip joint was imaged as a thin anechoic line, bounded laterally and medially by two echogenic lines, the acetabulum and femoral head respectively (Fig. 3A). The greater trochanter of the femur was imaged on the caudolateral portion of the femoral head as a hyperechoic convex arch (Fig. 3B). The imaging of the caudal portion of the hip joint was difficult. The tuber ischii appeared on the transverse scan as a smooth slightly convex hyperechoic curvilinear structure directed dorsoventrally, 
A. Sharshar et al.: Comparative ultrasonographic characterization of the pelvis in clinically normal horses and donkeys

is covered caudally by two homogenous hypoechoic masses with echogenic linear fiber pattern constituting semimembranosus and semitendinosus muscles (Fig. 3C). On the longitudinal scan, it appeared as a nearly straight, smooth hyperechoic line (Fig. 3D). The third trochanter appeared on the transverse scan as an inverted hyperechoic U-shape arch attached cranially to the femur. The tendon of insertion of the superficial gluteal muscle was attached to its apex and appeared ultrasonographically as an echogenic straight thick line directed cranially (Fig. 4A). On the longitudinal scan, the third trochanter appeared as a smooth hyper echoic curvilinear structure (Fig. 4B).
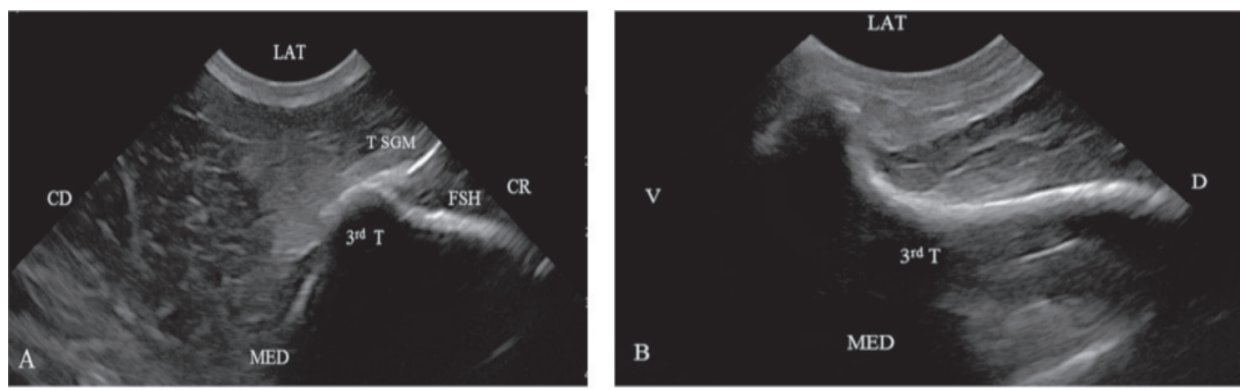

Fig. 4A - Transverse ultrasonographic image of the third trochanter $\left(3^{\text {rd }} \mathrm{T}\right)$ in a 7 year old donkey. It is attached medially to the femoral shaft ( $\mathrm{F} \mathrm{SH})$ and cranially to the tendon of insertion of the superficial gluteal muscle (T SGM). MED, medial, LAT, lateral, CR, cranial, CD, caudal. Fig. 4B

- Longitudinal ultrasonographic image of the third trochanter $\left(3^{\text {rd }} \mathrm{T}\right)$ of the same animal.

The pelvic symphysis was imaged during transrectal examination as a small echogenic area separating between two slightly concave hyperechoic lines comprising the ischiatic table. It was quite wide at the most caudal portion of the pelvic floor (Fig. 5A) and completely disappeared at the anterior third (Fig. 5B). During the longitudinal scan, the ischiatic table appeared as a slightly concave, smooth hyperechoic arch (Fig. $5 \mathrm{C}$ ). The obturator foramen appeared as an area of mixed echogenicity, bounded caudally and cranially by two convex hyperechoic arches constituting the ischiatic and pubic rims, respectively (Fig. 5D). The obturator blood vessels could be easily identified as two anechoic circular structures with well-defined echogenic borders, while the obturator nerve appeared as an echogenic structure located distally to the obturator blood vessels (Fig. 5D and 6A). The pubis and the pubic brim appeared as a smooth hyperechoic curvilinear structure with a bony prominence at its cranial end (Fig. 5D). 
A. Sharshar et al.: Comparative ultrasonographic characterization of the pelvis in clinically normal horses and donkeys
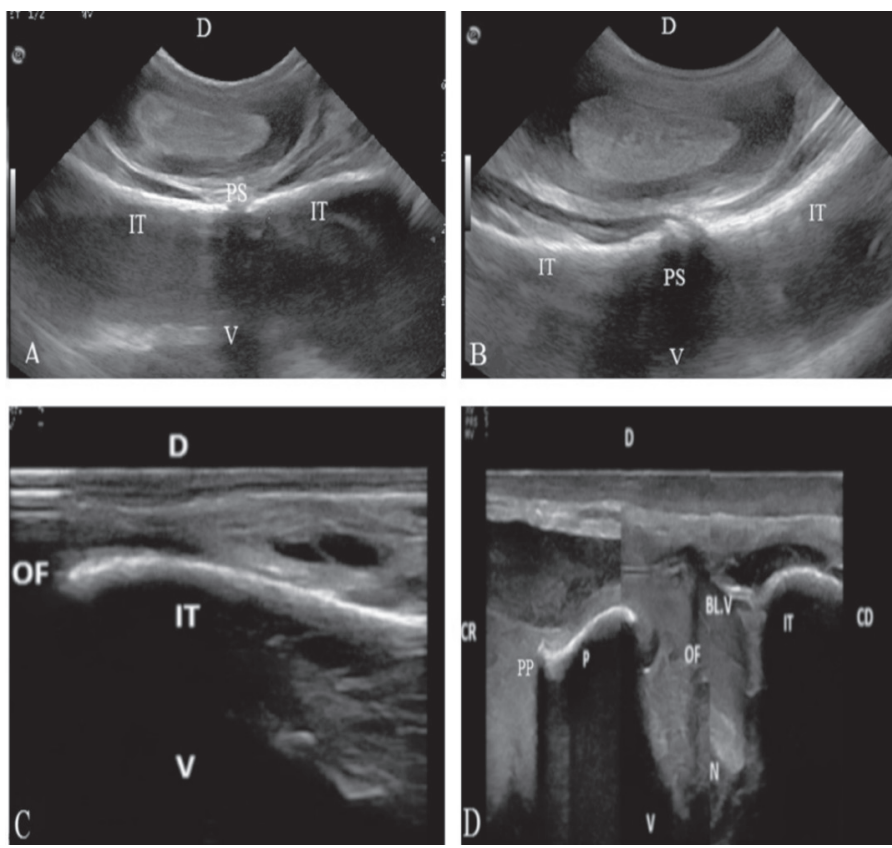

Fig. 5. A. Transverse ultrasonographic image of the caudal part of the pelvic floor in a 25year old stallion showing pelvic symphysis (PS) which appears as small echogenic area separated by two hyperechoic lines constituting the ischiatic tables (IT). D, dorsal, V, ventral. Fig. 5B - Transverse ultrasonographic image of the anterior third of the pelvic floor of the same animal. Note, the pelvic symphysis (PS) has completely disappeared by fusion of the ischiatic tables (IT). D, dorsal, $\mathrm{V}$, ventral. Fig. 5C - Longitudinal ultrasonographic image of the ischiatic table (IT) of the same animal. It appears as a slightly convex hyperechoic arch extending cranially to the obturator foramen (OF). D, dorsal, V, ventral. Fig. 5D. Compound longitudinal ultrasonographic image of the same animal in in Fig. 5A showing the obturator foramen (OF), pubis $(\mathrm{P})$ and pubic prim (PP).

The OF contains the obturator blood vessel (BL V) and nerve $(\mathrm{N})$. D, dorsal, V, ventral.

The medial aspect of the acetabulum appeared as a smooth convex hyperechoic arch, continuous with the medial aspect of the ilial body. The ilial body appeared as a slightly irregular, smooth hyperechoic linear structure extending craniodorsally (Fig. $6 \mathrm{~B})$. The sacroiliac joint appeared as a narrow anechoic band, bounded ventrally and dorsally by two slightly convex hyperechoic arches, constituting the first sacral transverse process and the ilial wing, respectively. The iliolumbar artery could be easily detected as a hypoechoic circular structure on the lateral portion of the sacroiliac joint (Fig. 6C). The mean width of the sacroiliac joint in both horses and donkeys is presented in Table 3 . The ventral aspect of the sacrum appeared as a slightly convex hyperechoic arch, interspersed with hypoechoic to echogenic half circle pit-like depressions at equal distances apart, 
A. Sharshar et al.: Comparative ultrasonographic characterization of the pelvis in clinically normal horses and donkeys

constituting the ventral sacral foramina (Fig. 6D). Each foramen was formed of a central core of mixed echogenicity and bounded by a bony hyperechoic rim.
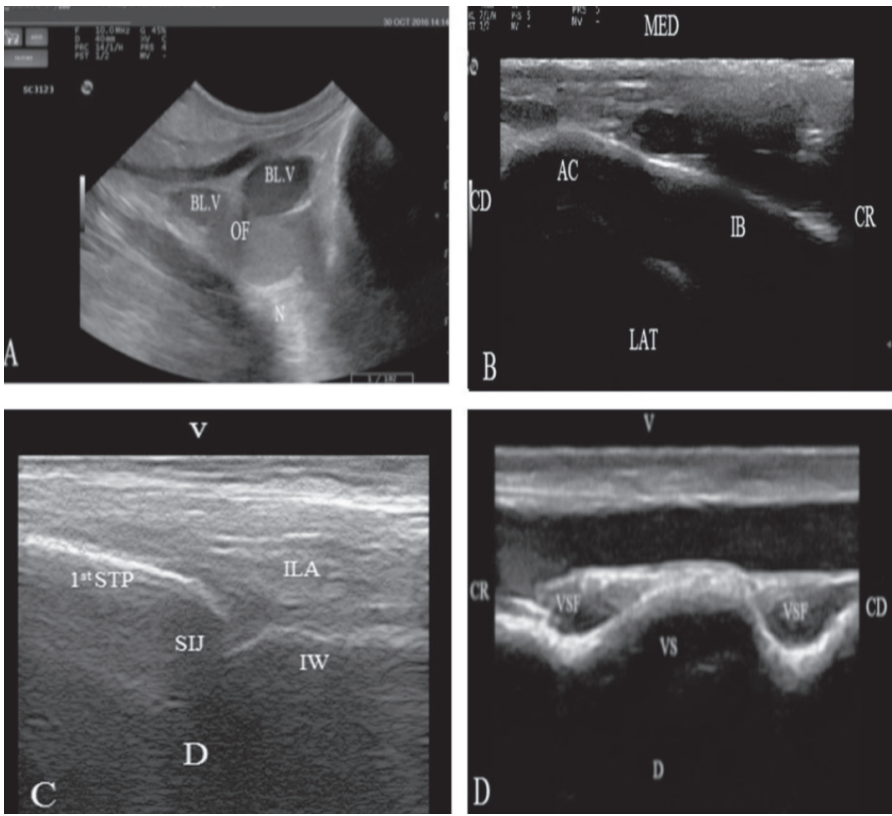

Fig. 6A - Transverse ultrasonographic image of the obturator foramen (OF) of the same animal as in Fig. 5D, showing the contents of the obturator foramen, including blood vessels (BL. V) and nerve $(\mathrm{N})$. Fig. 6B - Compound Longitudinal ultrasonographic image of the medial aspect of the acetabulum (AC) and ilial body (IB) in a 9 year old donkey. MED, medial, LAT, lateral, CR, cranial, CA, caudal. Fig. 6C - Ultrasonographic image of the left sacroiliac joint (SIJ) in an 8 year old donkey. It is bounded ventrally by the transverse process of the first sacral vertebra ( $\left.1^{\text {st }} \mathrm{STP}\right)$ and dorsally by the ilial wing (IW). The iliolumbar artery (ILA) could be located in the ventrolateral portion of the SIJ. V, ventral, D, dorsal. Fig. 6D - Longitudinal ultrasonographic image of the ventral aspect of the sacrum (VS) of a 15 year old stallion. It contains hypoechoic to echogenic half circle pit like depressions constituting the ventral sacral foramina (VSF). V, ventral, D, dorsal. 
A. Sharshar et al.: Comparative ultrasonographic characterization of the pelvis in clinically normal horses and donkeys

Table 3. The mean and standard error (SE) of the recorded pelvic measurements

\begin{tabular}{|l|c|c|c|c|}
\hline \multirow{2}{*}{ Measured item } & \multicolumn{2}{|c|}{$\begin{array}{c}\text { Horse } \\
\text { Mean } \pm \text { SE }\end{array}$} & \multicolumn{2}{c|}{$\begin{array}{c}\text { Donkey } \\
\text { Mean } \pm \text { SE }\end{array}$} \\
\cline { 2 - 5 } & \multicolumn{2}{|c|}{ Right } & Left & \multicolumn{2}{c|}{$2.92 \pm 0.07^{\mathrm{a}}$} \\
\hline $\begin{array}{l}\text { The distances between both } \\
\text { tubera sacralia (cm) }\end{array}$ & \multicolumn{2}{|c|}{$2.96 \pm 0.13^{\mathrm{a}}$} & $0.94 \pm 0.17^{\mathrm{a}}$ & $0.86 \pm 0.12^{\mathrm{a}}$ \\
\hline $\begin{array}{l}\text { The distance between tuber } \\
\text { sacral and skin surface (cm) }\end{array}$ & $1.04 \pm 0.05^{\mathrm{a}}$ & $1.08 \pm 0.05^{\mathrm{a}}$ & $1.60 \pm 0.07^{\mathrm{a}}$ & $1.58 \pm 0.06^{\mathrm{a}}$ \\
\hline $\begin{array}{l}\text { The distance between tuber } \\
\text { sacrale and first sacral spinous } \\
\text { process (cm) }\end{array}$ & $1.70 \pm 0.1^{\mathrm{a}}$ & $1.76 \pm 0.1^{\mathrm{a}}$ & & \\
\hline $\begin{array}{l}\text { The thickness of dorsal } \\
\text { portion of the dorsal sacroiliac } \\
\text { ligament - thoracolumbar } \\
\text { fascia combination (mm) }\end{array}$ & $4.1 \pm 0.2^{\mathrm{a}}$ & $4.05 \pm 0.2^{\mathrm{a}}$ & $3.93 \pm 0.15^{\mathrm{a}}$ & $3.92 \pm 0.1^{\mathrm{a}}$ \\
\hline $\begin{array}{l}\text { Cross sectional area of } \\
\text { both the dorsal sacroiliac } \\
\text { ligament- thoracolumbar fascia } \\
\text { combination (cm })^{2}\end{array}$ & $1.4 \pm 0.07^{\mathrm{a}}$ & $1.4 \pm 0.06^{\mathrm{a}}$ & $0.85 \pm 0.04^{\mathrm{b}}$ & $0.86 \pm 0.03^{\mathrm{b}}$ \\
\hline $\begin{array}{l}\text { Thickness of the lateral portion } \\
\text { of dorsal sacroiliac ligament } \\
\text { (mm) }\end{array}$ & $1.6 \pm 0.09^{\mathrm{a}}$ & $1.7 \pm 0.1^{\mathrm{a}}$ & $1.3 \pm 0.03^{\mathrm{a}}$ & $1.2 \pm 0.02^{\mathrm{a}}$ \\
\hline $\begin{array}{l}\text { Width of the sacroiliac joint } \\
\text { (mm) }\end{array}$ & $4.2 \pm 0.1^{\mathrm{a}}$ & $4.2 \pm 0.1^{\mathrm{a}}$ & $3.4 \pm 0.2^{\mathrm{b}}$ & $3.3 \pm 0.2^{\mathrm{b}}$ \\
\hline
\end{tabular}

Values with the same superscript litters have no significant difference, while values with different superscript litters have significant difference

\section{Discussion}

In equine, hind limb lameness caused by pelvic injuries or infections (bone fractures and/or ligament damage) is far more common than previously thought (WALKER et al, 2012; WHITCOMB, 2012). Ultrasound has been used for pelvic examination in recent years. It is accessible to most equine practitioners. It is also safe and can provide a rapid and accurate diagnosis (WHITCOMB, 2012; HEAD, 2014). Several reports have paid attention to ultrasonographic evaluation of the pelvis in both clinically normal, and affected horses and ponies (TOMLINSON et al, 2001; KERSTEN and EDINGER, 2004; ENGELI et al, 2006; WHITCOMB, 2012; WALKER et al, 2012 and HEAD, 2014). According to our knowledge, this may be the first report concerned with ultrasonographic evaluation of the pelvis in clinically normal donkeys. 
A. Sharshar et al.: Comparative ultrasonographic characterization of the pelvis in clinically normal horses and donkeys

Efficient planning is very important to save time and effort during pelvic examination (KOFLER, 2009; WALKER et al, 2012; HEAD, 2014; and WHITCOMB and VAUGHAN, 2015). For complete evaluation of the pelvis, both transcutaneous and transrectal techniques should be performed. This can be achieved safely by efficient animal restraint (WALKER et al, 2012). In this study, all animals were restrained in a stanchion, under xylazine tranquilization and caudal posterior epidural analgesia using lidocaine HCL $2 \%$. Caudal posterior epidural analgesia is very important for safe transrectal examination. It reduces animal straining as well as the chance of rectal tearing. From the technical and economical point of view, this technique was superior to that previously mentioned by WALKER et al (2012), who sprayed a large amount $(50 \mathrm{ml})$ of lidocaine intra-rectally to facilitate transrectal examination.

According to this study, a high similarity was found between horses' and donkeys' pelvises in terms of the ultrasonographic appearance of its structures. Our findings in that respect were found to be in accordance with previously published data (TOMLINSON et al, 2001; PILSWORTH, 2003; KERSTEN and EDINGER, 2004; WALKER et al, 2012; WHITCOMB, 2012; HEAD, 2014). The examined bone surfaces appeared as hyperechoic and linear, convex or concave structures with smooth or slightly irregular surfaces. In both horses and donkeys, tuber sacral, tuber coxae, and tuber ischii appeared as slightly convex hyperechoic arches (PILSWORTH, 2003; KERSTEN and EDINGER, 2004 and WHITCOMB, 2012; HEAD, 2014). The tuber sacrale showed slight irregularity on its surface (TOMLINSON et al., 2001; ENGELI et al., 2006). Such findings should not be misdiagnosed as pathological changes to the tuber sacrale, and require careful monitoring and examination of the contralateral side to rule out such changes (TOMLINSON et al, 2003).

In our study, we imaged the proximal part of first sacral spinous process as a small hyperechoic area located midway between the two tubera sacrales. The distance between the tuber sacrale and the first sacral spinous process showed no significant difference between horses and donkeys, or between the right and left sides. The Ilial wing and body appeared in both horses and donkeys as continuous hyperechoic concave arches. These results found are in accordance with previous reports (PILSWORTH, 2003; HEAD, 2014). In our study, we imaged a gap-like fracture during ultrasonographic examination of the ilial wing med-region. This finding was excluded after dissection studies. This artifact may be a result of the scattering of the ultrasound beam on the surface of the accessory gluteal muscle tendon that inserted at med-ilial wing. This finding should not be misdiagnosed as a fracture. This may be avoided by careful evaluation and proper probe orientation during the examination (WHITCOMB, 2012).

Infections or injuries to the pelvic ligaments and tendons constitute the most common back soft tissues injuries in horses (HAUSSLER et al. 1999). Their evaluation, in terms of 
A. Sharshar et al.: Comparative ultrasonographic characterization of the pelvis in clinically normal horses and donkeys

echogenicity and measurement, should be performed carefully during pelvic examination. The thoracolumbar fascia showed two different configurations relative to the dorsal portion of the dorsal sacroiliac ligament. The predominate configuration was seen in two thirds of the examined horses and all the examined donkeys, in which the thoracolumbar fascia fused to the medial aspect of the dorsal portion of the dorsal sacroiliac ligament. The less frequently encountered configuration was seen in one third of the examined horses, where the thoracolumbar fascia fused dorsally to the dorsal portion of the dorsal sacroiliac ligament. These results are in accordance with data previously published by ENGELI et al, 2006. Due to difficulties in ultrasonographic differentiation between the dorsal portion of the dorsal sacroiliac ligament and the thoracolumbar fascia at the point of their fusion (the most dorsal point of the tuber sacrale), the thickness and cross-sectional area of the entire fused portion were evaluated and compared with the opposite side. According to this study, the thickness of the fused portion of the dorsal part of the dorsal sacroiliac ligament-thoracolumbar fascia combination showed no significant differences between horses and donkeys, whereas the cross-sectional area of both structures showed significant differences between them. In our opinion, this variation in measurements between horses and donkeys may be attributed to the configuration by which the thoracolumbar fascia is attached to the dorsal portion of the dorsal sacroiliac ligament (in horses two configurations were detected, while in donkeys only one configuration was detected). Evaluation of the lateral portion of the dorsal sacroiliac ligament at its attachment to the lateral sacral crest is very important because an inflammation or rupture may cause acute hind limb lameness (HAUSSLER et al., 1999).

The deep location and excessive musculature surrounding the hip joint make its localization and examination difficult. It may be easily located at the caudoventral end of the ilial body at the point of its surface variance from concave to convex. Our results concerning the appearance of the hip joint in both horses and donkeys are in accordance with previously published data (WALKER et al., 2012; WHITCOMB and VAUGHAN, 2015). Transcutaneous ultrasonographic evaluation of the hip joint may be limited to abnormalities involving the cranial head of the femur and acetabulum. This may be attributed to the deep location of the femoral head within the acetabulum, and the presence of the greater trochanter which prevent complete evaluation of the femoral head and the caudal portion of the hip joint (HOGAN et al., 1995; DYSON and MURRAY, 2003). For complete evaluation of the hip joint, transrectal examination of the obturator foramen and the medial aspect of the acetabulum is required, especially when an acetabular fracture and/or femoral head luxation are suspected (BRENNER and WHITCOMB, 2009). Although the third trochanter is not part of the bony pelvis, its evaluation is very important and constitutes part of a pelvic evaluation, because its fracture or fragmentation constitute one of the main causes of sudden hind limb lameness (WHITCOMB, 2012; HEAD, 2014; SHIELDS et al., 2015). 
A. Sharshar et al.: Comparative ultrasonographic characterization of the pelvis in clinically normal horses and donkeys

For complete pelvic evaluation, besides a transcutaneous examination, a fully and sequential transrectal examination should be performed. Following the anatomical landmarks is important to locate different pelvic structures (HEAD, 2014). Whatever the age of the examined animal, the pelvic symphysis may be easily identified in the posterior two thirds of the pelvic floor and it completely disappears at the anterior third (WALKER et al, 2012, and WHITCOMB, 2012). Such findings should not be misdiagnosed as ischiatic table gap fracture. From the obstetrical point of view, evaluation of the medial aspect of the ilial body and the sacrum are of clinical importance. A fracture may cause the internal pelvic dimensions to collapse and distort, which may affect the animal's reproductive performance and predispose it to dystocia (WHITCOMB, 2012; GUNDELACH et al., 2013).

Regardless of the differences in their body weight and size horses and donkeys showed no significant differences in the pelvic measurements evaluated in this study, apart from the cross sectional area of both dorsal portions of the dorsal sacroiliac ligament- thoracolumbar fascia combination and the width of the sacroiliac joint. Careful evaluation of different pelvic measurements is very important to detect the cause of pelvic asymmetry. According to (GILLIS, 1999), evaluation of the depth of the tubera sacrales from the skin surface is helpful in diagnosis of sacroiliac joint subluxation. However, KERSTEN and EDINGER (2004) disagreed with this opinion. They referred to left to right asymmetry in that respect only in terms of soft tissue lesion, and said that diagnosis of sacroiliac joint subluxation is not possible on the basis of this measurement alone. They added that, diagnosis of sacroiliac joint subluxation by the transcutaneous approach requires measuring and comparing the distance from the right and left tuber sacrale to the most dorsal part of the first sacral spinous process. However, in their study they failed to image it. In another study, the authors relied on the importance of measuring the distance between the tubera sacrales and the skin surface in evaluation of both soft and hard tissue related asymmetry (ENGELI et al, 2006). In the authors' opinion, depending upon one measurement to detect the cause of right to left pelvic asymmetry may be not helpful. It requires careful evaluation and combinations of more than one measurement. That is to say, the transcutaneous approach for evaluation of sacroiliac joint abnormalities is not sufficient to give a complete picture of joint status, due to its deep location and the bony structures surrounding it (TOMLINSON et al, 2001; KERSTEN and EDINGER, 2004; ENGELI and HAUSSLER, 2012). For complete evaluation of the sacroiliac joint, a combination of transcutaneous and transrectal examinations is required. In transcutaneous examination, the depth of the tubera sacrales from the skin surface and the distance between each tuber sacrale and the first sacral spinous process should be evaluated. In a transrectal examination the width of the joint space should be evaluated. The presence of asymmetry in measurements between the two sides may be attributed to luxation or subluxation of the sacroiliac joint. 
A. Sharshar et al.: Comparative ultrasonographic characterization of the pelvis in clinically normal horses and donkeys

\section{Conclusion}

Ultrasonography is a readily available, efficient, safe and inexpensive diagnostic tool for evaluation of the bony and soft structures of the pelvis under field conditions where other tools are not available. A donkey's pelvis has the same ultrasonographic appearance as a horse, with no significance differences between them in their measurements, apart from the cross-sectional area of the dorsal portion of the dorsal sacroiliac ligament thoracolumbar fascia combination, and the width of the sacroiliac joint. Concerning the ultrasonographic appearance of the pelvis, the results obtained are highly suggestive that records of ultrasonographic examinations of a horse's pelvis may be used as a guide for pelvic evaluation of donkeys.

\section{Acknowledgements}

The authors gratefully acknowledge the assistance of Dr. Ahmed Mousa, Department of Biochemistry, Faculty of Veterinary Medicine, University of Sadat City, Egypt for his assistance in performing statistical analysis of the collected parameters. We would also like to thank the staff within our department who contributed to the care of the examined horses and donkeys.

\section{References}

ALMANZA, A., M. B. WHITCOMB (2003): Ultrasonographic diagnosis of pelvic fractures in 28 horses. $49^{\text {th }}$ Annual Convention of the American Association of Equines. 50-54.

BARRETT, E. L., A. M. TALBOT, A. J. DRIVER (2006): A technique for radiography in the standing horse. Equine Vet. J. 38, 266-270.

DOI: $10.2746 / 042516406776866435$

BERTONI, L., M. SEIGNOUR, M. De MIRA (2013): Fractures of the third trochanter in horses: 8 cases (2000-2012). J. Am. Vet. Med. Assoc. 243, 261-266.

DOI: $10.2460 /$ javma.243.2.261

BRENNER, S., M. B. WHITCOMB (2009): Ultrasonographic diagnosis of coxofemoral subluxation in horses. J. Vet. Radiology \& Ultrasound. 50,423-8.

DOI: 10.1111/j.1740-8261.2009.01560.x

BUTLER, J. A., C. M, COLLES, S. J., DYSON (2008): The pelvis and the femur. In: Clinical Radiology of the Horse (Butler J. A., C. M. Colles, S. J. Dyson, Eds.), $3^{\text {rd }}$ ed., Wiley-Blackwell, Oxford, England, pp. 573-601.

DAVENPORT-GOODALL, C. L. M., M. W. ROSS (2004): Scintigraphic abnormalities of the pelvic region in horses examined because of lameness or poor performance: 128 cases (19932000). J. Am. Vet. Med. Assoc. 224, 88-95.

DOI: $10.2460 /$ javma.2004.224.88 
A. Sharshar et al.: Comparative ultrasonographic characterization of the pelvis in clinically normal horses and donkeys

DEWÉ, T. C. M., I. C. FULTON, B. H. ANDERSON (2008): Scintigraphic diagnosis of greater trochanter, third trochanter, tuber coxae and tuber ischii injuries in the racing Thoroughbred: 43 cases (2002-2008). Australian Equine Veterinary Association. 27, 48.

DYSON, S., R. MURRAY (2003): Pain associated with the sacroiliac joint region: a clinical study of 74 horses. Equine Vet. J. 35, 240-245.

DOI: $10.2746 / 042516403776148219$

DYSON, S., R. MURRAY, M. BRANCH, E. HARDING (2003a): The sacroiliac joints: evaluation using nuclear scintigraphy. Part 2: Lame horses. Equine Vet. J. 35, 233-239.

DOI: $10.2746 / 042516403776148219$

DYSON, S., R. MURRAY, M. BRANCH, C. WHITTON, T. DONOVAN, E. HARDING (2003b): The sacroiliac joints: evaluation using nuclear scintigraphy. Part 1: The normal horse. Equine Vet. J. 35, 226-232.

DOI: $10.2746 / 042516403776148255$

ENGELI, E., K. K. HAUSSLER (2012): Review of injection techniques targeting the sacroiliac region in horses. Equine Vet. Educ. 24, 529-541.

DOI: $10.1111 / \mathrm{j} .2042-3292.2011 .00313 . x$

ENGELI, E., A. E. YEAGER, H. ERB, K. K. HAUSSLER (2006): Ultrasonographic technique and normal anatomic features of the sacroiliac region in horses. Vet. Radiol. Ultrasound 47, 391-403.

DOI: $10.1111 / \mathrm{j} .1740-8261.2006 .00159 . x$

ERICHSEN, C., M. BERGER (2001): Pitfalls in the interpretation of pelvic scintigrams caused by soft tissue attenuation. ABSTRACTS FROM THE TWELFTH MEETING OF THE INTERNATIONAL VETERINARY RADIOLOGY ASSOCIATION OBIHIRO-JAPAN. Vet. Radiol. Ultrasound 42, 169-187.

DOI: $10.1111 / j .1740-8261.2001 . t b 00921 . x$

GEISSBÜHLER, U., A. BUSATO, G. UELTSCHI (1998): Abnormal bone scanfindings of the equine ischial tuberosity and third trochanter. Vet. Radiol. Ultrasound 39,572-7.

DOI: $10.1111 / j .1740-8261.1998 . t b 01654 . x$

GILLIS, C. (1999): Spinal ligament pathology. Veterinary Clinics: Equine Practice 15, 97-101. DOI: org/10.1016/S0749-0739(17)30166-9

GUNDELACH, Y., T. SCHULZ, M. FELDMANN, M. HOEDMAKER (2013): Effect of increased vigilance for locomotion disorders of lameness and production in dairy cows. Animals 3, 951961.

DOI: $10.3390 /$ ani3030951

HAUSSLER, K. K., S. M. STOVER, N. H. WILLITS (1999): Pathologic changes in the lumbosacral vertebrae and pelvis in Thoroughbred racehorses. Am. J. Vet. Res. 60,143-153.

HEAD, M. (2014): Ultrasonography of the pelvis. In: Atlas of Equine Ultrasonography (Kidd, J. A., K. G. Lu, M. L Frazer, Eds.), 1 ${ }^{\text {st }}$ ed., John Wiley \& Sons, Ltd., pp. 183-197. 
A. Sharshar et al.: Comparative ultrasonographic characterization of the pelvis in clinically normal horses and donkeys

HOGAN, P. M., W. V. BERNARD, B. A. HOWARD (1995): What is your diagnosis? Osteomyelitis of the right tuber coxa. J. Am. Vet. Med. Assoc. 207, 415-416.

KERSTEN, A. A. M., J. EDINGER (2004): Ultrasonographic examination of the equine sacroiliac region. Equine Vet. J. 36, 602-608.

DOI: $10.2746 / 0425164044864480$

KOFLER, J. (2009): Ultrasonography as a Diagnostic Aid in Bovine Musculoskeletal Disorders. Vet. Clin. Food Anim. 25, 687-731

DOI: $10.1016 /$ j.cvfa.2009.07.011

PILSWORTH, R. C. (2003): Diagnosis and management of pelvic fractures in the thoroughbred racehorse. In: Diagnosis and Management of Lameness in the Horse (Ross, M. W., S. J. Dyson, Eds). Philadelphia, PA, Saunders, pp. 484-490.

PILSWORTH, R. C. (2011): Diagnosis and management of pelvic fractures in the thoroughbred racehorse. In: Diagnosis and Management of Lameness in the Horse. (Ross, M. W., S. J. Dyson, Eds), $2^{\text {nd }}$ ed. St. Louis, MO: Elsevier, pp. 564-571.

POWELL, S. (2011): Investigation of pelvic problems in horses: equine practice. 33, 518-524. DOI. org/10.1136/inp.d7331

SHIELDS, G. E., M. B. WHITCOMB, B. VAUGHAN, E. R. WISNER (2015): Abnormal imaging findings of the femoral third trochanter in 20 horses. Vet. Radiol. Ultrasound. 56, 466-473.

DOI: $10.1111 /$ vru. 12262

TOMLINSON, J.E., A. M. SAGE, T. A. TURNER, D. A. FEENEY (2001): Detailed ultrasonographic mapping of the pelvis in clinically normal horses and ponies. Am. J. Vet. Res. 62, 1768-1775.

DOI: 10.2460/ajvr. 2001.62.1768

TOMLINSON, J. E., A. M. SAGE, T. A. TURNER (2003): Ultrasonographic abnormalities detected in the sacroiliac area in twenty cases of upper hind limb lameness. Equine Vet. J. 35, 48-54.

DOI: $10.2746 / 042516403775467540$

TRUMP, M., P. R. KIRCHER, A. FÜRST (2011): The use of computed tomography in the diagnosis of pelvic fractures involving the acetabulum in two fillies. Vet. Comp. Orthop. Traumatol. 24, 68-71.

DOI: 10.3415/VCOT-10-04-0067; PMID: 21103652

VERHEYEN, K. L. P., J. L. N. WOOD (2004): Descriptive epidemiology of fractures occurring in British Thoroughbred racehorses in training. Equine Vet. J. 36, 167-73.

DOI: $10.2746 / 0425164044868684$

WALKER, W. T., N. M. WEEPY, L. R. GOODRICH (2012): Procedure for the Transrectal and Transcutaneous Ultrasonographic Diagnosis of Pelvic Fractures in the Horse. Journal of Equine Veterinary Science 32, 222-230.

DOI. org/10.1016/j.jevs.2011.09.067

WHITCOMB, M. B. (2012): Ultrasonographic Evaluation of the Equine Pelvis. Proceedings of the AAEP Focus on Hind Limb Lameness, pp. 1-9. 
A. Sharshar et al.: Comparative ultrasonographic characterization of the pelvis in clinically normal horses and donkeys

WHITCOMB, M. B., J. DOVAL, J. PETERS (2011): The use of computed tomographic threedimensional reconstructions to develop instructional models for equine pelvic ultrasonography. Vet. Radiol. Ultrasound 52, 542-547.

DOI: $10.1111 / \mathrm{j} .1740-8261.2011 .01840 . \mathrm{x}$

WHITCOMB, M. B., B. VAUGHAN (2015): Ultrasonographic Evaluation of the Coxofemoral Joint. Proceedings of the $61^{\text {st }}$ Annual Convention of the American Association of Equine Practitioners, Las Vegas, Nevada, USA, pp. 346- 354.

Received: 24 July 2017

Accepted: 25 January 2018

\section{SHARSHAR, A., M. EL-SUNSAFTY, T. MISK, S. GADALLAH, M. FADEL: Usporedna ultrazvučna karakterizacija zdjelice kod klinički zdravih konja i magaraca. Vet. arhiv 88, 607-625, 2018.}

SAŽETAK

Istraživanje je provedeno kako bi se dobio detaljan usporedni ultrazvučni opis zdjelice kod klinički zdravih konja i magaraca. Uključeno je 48 odraslih životinja, 30 konja i 18 magarca. Zdjelica je analizirana transkutanom i transrektalnom tehnikom. Istražene su sljedeće strukture: križne kvrge (oblik i udaljenost između njih te udaljenost između svake od njih i prvoga križnog šiljastog nastavka), krilo bočne kosti, bočna kvrga, trup bočne kosti, kuk, sjedna kvrga, treći trohanter, izgled i mjere dorzalnih i lateralnih dijelova dorzalnog sakroilijačnog ligamenta i torakolumbalne fascije, ploča sjedne kosti, zastrti otvor i njegov sadržaj, preponska kost, medijalni dio acetabuluma i tijela bočne kosti, sakroilijačni zglob i ventralni dio križne kosti. Podaci dobiveni za svaku strukturu podvrgnuti su usporednoj analizi između konja i magaraca. Nađena je visoka podudarnost oblika i mjera dobivenih ultrazvukom zdjelica kod konja i magaraca, s izuzetkom obaju područja kombinacije između dorzalnog dijela dorzalnog sakroilijačnog ligamenta - torakolumbalne fascije i širine sakroilijačnog zgloba koji su između ovih dviju vrsta pokazali signifikantne razlike.

Ključne riječi: magarac, konj, ultrazvuk zdjelice, transkutano, transrektalno 
